\title{
Effects of continuous nitrogen addition on the quality of Leymus chinensis and soil properties in saline-sodic soil of Northeast China
}

\author{
Lu Zhang ${ }^{1}$, Li-Hua Huang ${ }^{1}$, Jia Na ${ }^{1}$, Yimin Yan ${ }^{1}$, Mingming Wang ${ }^{1}$, Zheng-Wei Liang ${ }^{2}$, \\ Zhichun Wang ${ }^{3}$, and Jinxin Huang ${ }^{1}$ \\ ${ }^{1}$ Northeast Institute of Geography and Agroecology Chinese Academy of Sciences \\ ${ }^{2}$ University of the Chinese Academy of Sciences \\ ${ }^{3}$ Chinese Academy of Sciences
}

September 11, 2020

\begin{abstract}
Leymus chinensis (Trin.) Tzvel. (Poaceae) is the dominant plant species in the Songnen grassland of China. Nitrogen addition is an important measure to prevent degradation of grassland due to soil salinization. To clarify the effects of long-term nitrogen addition on the quality of L. chinensis and soil properties, a field experiment was continuous conducted for 10 years in moderately saline-sodic grassland from 2009 to 2018 , and the annual nitrogen addition rate was $0,30,60,90,120,150,180$ and $210 \mathrm{~kg} \mathrm{~N}$ ha-1, respectively. The results showed that with nitrogen addition rates increasing, the contents of protein and fat in shoot increased $20.5 \%$ to $80.9 \%$ and $6.9 \%$ to $69.3 \%$ compared with those of the control without nitrogen addition, respectively. When nitrogen addition rates reached $90 \mathrm{~kg}$ ha- 1 to $210 \mathrm{~kg}$ ha- 1 , The ratio of $\mathrm{K}+/ \mathrm{Na}+$ and $\mathrm{Ca} 2+/ \mathrm{Na}+\mathrm{in} \mathrm{L}$. chinensis shoot increased 1.26 to 3.37 times and 1.56 to 2.98 times compared with those of the control, respectively. Nitrogen addition decreased significantly soil $\mathrm{pH}$, electrical conductivity and exchange sodium percentage, and increased significantly the contents of soil organic matter, total nitrogen, available nitrogen, the activities of sucrase and urease and ecosystem multifunctionality $\left(\mathrm{P}_{j} 0.05\right)$. The redundancy analysis showed that there was a significant positive correlation between the improvement of L. chinensis quality and soil desalination and soil fertility increasing. Therefore, the suitable nitrogen addition rate of 90-120 kg N ha- 1 was an effective and necessary measure to maintain the healthy growth of L. chinensis and inhibit land degradation in moderately saline-sodic grassland of Northern China.
\end{abstract}

Abbreviations : L. chinensis, Leymus chinensis ; DASLES, Da'an Sodic Land Experiment Station; CAS, Chinese Academy of Sciences; MSSL, moderately saline-sodic grassland; SSSL, severely saline-sodic grassland; N, nitrogen; EC, electrical conductivity; ESP, exchangeable sodium percentage; SOM, soil organic matter; TN, total nitrogen, $\mathrm{AN}$, available nitrogen; $\mathrm{C} / \mathrm{N}$, the ratio of carbon to nitrogen; RDA, Redundancy analysis; EMF, ecosystem multifunctionality.

\section{Introduction}

Soil salinization is a worldwide environmental degradation problem. According to the statistics of FAO/UNESCO, the total area of salt affected soils is up to 100 million hectares, accounting for about $6 \%$ of the total land area in the world (Wong et al. , 2009; Hajiboland, 2013; Singh, 2015). With the global climate changing and increasing of the population, the area of salt affected soil is also increasing rapidly (Setia et al. , 2013).Due to soil salinization aggravating, many plants are facing unprecedented challenges. Taking Songnen Plain in as an example, soil salinization had resulted in a sharp decrease of grassland area by $64 \%$ from 1954 to 2000, most of which became saline-sodic wasteland (Wang et al ., 2009).

Leymus chinensis (Trin.) Tzvel.(Poaceae) is a perennial rhizome grass and the natural dominant species 
in the western grassland of Songnen Plain in (Zhu, 2004). It has strong drought resistance, saline-alkali tolerance and low temperature resistance (Wang et al ., 1994; Bai et al. , 2004; Jin et al ., 2008). However, with the increasing of human interference in this area, overgrazing, reclaiming farmland, collecting soil and other production activities further aggravated soil salinization and sodicization, which to result to the continuous decline of soil fertility and further degradation of L. chinensisgrasslands (Gao et al. , 2015; Qin et al ., 2016).

Numerous studies have shown that nutrients addition was an important measure to improve soil fertility and maintain high productivity of grassland, especially nitrogen $(\mathrm{N})$ fertilizer addition was widely used in pasture land (Han et al ., 2007; Clark \& Tilman, 2008). Also, N fertilizer addition can be used as soil restoration method in infertile or salt-affected soils (Murtaza et al ., 2000). As one of the key nutrient elements, N addition can promote leaf chlorophyll (Song et al ., 2016) and crude protein contents of L. chinensis (Hu et al ., 2017), and increase the hay yield and quality of L. chinensis (Qi et al ., 2013; Song et al ., 2016). Meanwhile, high soil N mineralization (Zhang et al ., 2009) and nitrification rates (Qin et al ., 2016) were observed in the pasture which $\mathrm{N}$ addition. However, Zhang et al. (2008) found that excessive $\mathrm{N}$ addition led to inefficient utilization of $\mathrm{N}$ fertilizers, and increased nitrate leaching and high environmental risks (Qin et al ., 2016). According to different soil types and plant species, the reasonable amount of $\mathrm{N}$ addition determined the crop yield and ecosystem stability (Vitousek et al ., 2009). The effects of $\mathrm{N}$ addition on the characteristics of plant or soil were often demonstrated lively in terms of ecosystem mutifunctionality (EMF) . Therefore, the study of EMF driven by plant or soil characteristics had become a recently hot spot in various ecosystem researchs (Hector \& Bagchi, 2007; Manning et al ., 2018; Jing et al ., 2015), while the research on the EMF affected by salts had received little attention.

Given the acknowledged importance of rational nutrients addition on ecologically fragile area, studying the effects of $\mathrm{N}$ addition on L. chinensis performance and ecosystem stability would provide a new insight on ecosystem productivity and saline-sodic land restoration. So we had established a field experiment about the effects of $\mathrm{N}$ addition on L. chinensis in two kinds saline-sodic soils since 2009, and the effects of continuous application of $\mathrm{N}$ on hay yield and seed yield of $L$. chinensis were also reported successively, and the previous studies demonstrated that reasonable $\mathrm{N}$ addition could improve the biomass and seed yield of L. chinensis (Huang et al ., 2015 \& 2019). However, the effects of long-term continuous $\mathrm{N}$ addition on the quality of $L$. chinensis, the characteristics of soil salt and the stability of ecosystem need to be further studied. Thus, the purposes of this study were (i) to reveal the effect of long-term continuous $\mathrm{N}$ addition on the nutritional quality of L. chinensis, (ii) to clarify the effect of long-term $\mathrm{N}$ addition on the salt characteristics of salinesodic soil, (iii) to analyze comprehensively the roles of $\mathrm{N}$ addition on the restoration of saline-sodic grassland and EMF in Northeast China.

\section{Materials and methods}

\subsection{Experimental site}

The field experiment of this study has been carried out for 10 years since Da'an Sodic Land Experiment Station (DASLES), Chinese Academy of Sciences (CAS) (45 35'58" ${ }^{\prime} 45 \mathrm{deg} 36^{\prime} 28^{\prime \prime} \mathrm{N}, 123 \mathrm{deg} 50^{\prime} 27^{\prime \prime}$ $\left.123 \mathrm{deg} 51^{\prime} 31^{\prime} \mathrm{E}\right)$, which is located in Da'an city of Jilin Province of China. The DASLES is a typical saline degraded grassland ecosystem located in the Western of Songnen Plain,. The area is semi-arid with a temperate continental climate. The annual mean temperature is $4^{\sim}$, the annual mean precipitation is $350^{\sim}$ in the area. While evaporation is about, which is $4^{\sim} 5$ times of the precipitation.

The original field experiment was conducted in two different kinds of saline-sodic grassland: moderately saline-sodic grassland (MSSL), with soil $\mathrm{pH} 8.94$ and ECe $5.7 \mathrm{dS} \mathrm{m}^{-1}$, and severely saline-sodic grassland (SSSL), with soil $\mathrm{pH} 9.80$ and ECe $8.8 \mathrm{dS} \mathrm{m}^{-1}$. This study was only carried out in MSSL, for other basic chemical characteristics of grassland soils, please refer to our previous studies (Huang et al. , 2015 \& 2019).

2.2 Experimental design 
The experiment was a completely randomized block design, with 3 replicates in MSSL. Eight $\mathrm{N}$ addition levels were 0 (control),30,60,90,120,150, 180 and $210 \mathrm{~kg} \mathrm{~N} \mathrm{ha}^{-1}$, respectively. The area of each plot was $9 \mathrm{~m}^{2}$ ( 3 by $3 \mathrm{~m}$ ), and there were 24 plots in total. There was a 1-m gap between adjacent plots with separation maintained by cement boards installed to a depth of $10 \mathrm{~cm}$ in the soil. The experiment sites had been fenced and they had never received fertilizer before the experiment was started.

Nitrogen was added as urea (the content of pure $\mathrm{N} 46.2 \%$ ), when the L. chinensis resumed growth in the middle of May once a year, $\mathrm{N}$ fertilizer was applied to the surface of the L. chinensisgrassland in the early evening since 2009. After $\mathrm{N}$ addition, $10 \mathrm{~mm}$ water was slowly and evenly sprayed to each plot to make urea granule quickly dissolved and reduce the loss of fertilizer caused by volatilization. The same field management was applied to each plot, and maintained $L$. chinensis natural growth without human interference.

\subsection{Sampling and measurement methods}

According to the cutting habits of local L. chinensis as forage, it is usually harvested in early September every year. Thus, the plant and soil samples of the L chinensis were collected in early September in 2018. The sampling was carried out at random sites with a sampling size of 0.5 by $0.5 \mathrm{~m}$, with three replications within each plot. The plant samples were cut the shoot at ground level in a sampling size zone, put them into the oven and killed green at 105 for $2 \mathrm{~h}$, oven dried at 65 for $12 \mathrm{~h}$, and then grated them less than $1 \mathrm{~mm}$. The soil samples were randomly taken three soil cores (diameter of $40 \mathrm{~mm}$ ) at 0 to $20 \mathrm{~cm}$ depth within each plot, then mixed well and air dried, passed through a 2-mm sieve and then measured for the concentrations of soil salinity, nutrients and soil enzyme activities.

The protein content of $L$. chinensis was determined by continuous flow analyzer (SKALAR SAN++), the fat content was determined by soxhlet extraction method, the coarse fiber content was determined by acid-base washing method, the ash content was determined by using burning method of high temperature at 550+20 , and the concentrations of $\mathrm{K}^{+}, \mathrm{Na}^{+}, \mathrm{Ca}^{2+}$ and $\mathrm{Mg}^{2+}$ were determined by ICPS-7500 plasma emission spectrometer after the plant samples were combined digestion by nitric acid and perchloric acid (Bao, 2000),

Soil salinity and nutrients were measured by using conventional methods, and the specific methods were the same as those in our previous study (Huang et al., 2015). The related soil enzyme activities were determined by using the method of Guan et al . (1986), soil samples were cultured in a constant temperature incubator at 37 for $24 \mathrm{~h}$, and then soil urease activity was determined by sodium hypochlorite phenol colorimetry, soil catalase activity was determined by potassium permanganate titration, and soil sucrase activity was determined by 3,5-Dinitrosalicylic acid colorimetry.

\subsection{Statistical analysis}

The data were expressed as mean +- 1 SE. The treatments were run for a one-way ANOVA using the software of $\mathrm{R}$ version 3.5.2. Redundancy analysis (RDA) was implemented with the vegan package in the software $\mathrm{R}$. The EMF was as a uniteless index that usually combines soil characters and plant performance indexes, such as soil fertility, $\mathrm{N}$ cycling and plant productivity. Here, we examined 17 indexes including soil pH, EC, ESP, available nitrogen (AN), total nitrogen (TN), soil organic matter (SOM), catalase activity, urease activity, sucrose activity, and plant coarse protein, fat, coarse fiber, ash, $\mathrm{K}^{+}, \mathrm{Na}^{+}, \mathrm{Ca}^{2+}, \mathrm{Mg}^{2+}$ concentrations under different $\mathrm{N}$ addition rates. The averaging-based EMF measure was applied on Z-score transformed data to calculate the EMF value into a single index. The EMF of different treatments was compared through one-way ANOVA analysis followed by the Duncan's test. The relationship between EMF and N addition rates was best fitted by quadratic equation model, with the highest determinate coefficient. Other figures in this article were manufactured by Origin Pro 8.0 (Microcal, Malvern, England).

\section{Results}

3.1 The quality of $L$. chinensis

3.1.1 Protein and fat 
The crude protein content of $L$. chinensis increased significantly from $2.73 \%$ to $4.94 \%$ with $\mathrm{N}$ addition increasing $(P \nmid 0.05)$. In particular, when $\mathrm{N}$ addition rate was from $0 \mathrm{~kg} \mathrm{ha}^{-1}$ to $90 \mathrm{~kg} \mathrm{ha}^{-1}$, the crude protein content of L.chinensis increased in a straight line (Fig. 1A). Compared with the control, the protein content increased $20.5 \%, 38.5 \%$ and $66.3 \%$, respectively. However, the protein content increasing was no significance when $\mathrm{N}$ addition was more than $90 \mathrm{~kg} \mathrm{ha}^{-1}(P$ [?]0.05). In all treatments, the crude protein content of L.chinensis was the highest when $\mathrm{N}$ addition rate reached $150 \mathrm{~kg} \mathrm{ha}^{-1}$, and increased by $80.9 \%$ more than that of the control.

Similarly, the fat content of $L$. chinensis also increased markedly with increasing of N addition rates (Fig.1B). The fat contents of $\mathrm{N}$ addition treatments increased 6.9\%-69.3\% compared with that of the control, and the difference was very significant $(P ; 0.05)$. While $\mathrm{N}$ addition rate reached $90-210 \mathrm{~kg} \mathrm{ha}^{-1}$, there was no significant differences between the fat contents of each treatment $(P$ ¿0.05).

\subsubsection{Coarse fiber and ash}

The coarse fibers content of $L$. chinensis showed an overall downward trend with $\mathrm{N}$ addition rates increasing (Fig.1C). Compared with the control, the coarse fibers content reduced by $1.0 \%$ to $16.3 \%$ with $\mathrm{N}$ addition increasing, but there was no significant differences between most test treatments $(P$ ¿0.05).

It was different from the protein, fat and coarse fibers, there was almost no significant difference in the ash content of $L$. chinensis under different $\mathrm{N}$ addition treatments (Fig.1D). In MSSL, the ash content of $L$. chinensis was kept 4\%-5\%, and $\mathrm{N}$ addition had little effect on ash content of L. chinensis .

\subsubsection{Main mineral elements}

With different $\mathrm{N}$ addition rates increasing, the total content of mineral elements in L. chinensis shoot showed an increasing trend (Fig.2). Specifically, the contents of $\mathrm{K}^{+}$and $\mathrm{Ca}^{2+}$ in shoot increased significantly with $\mathrm{N}$ addition rate increasing $(P ; 0.05)$, on the contrary, the content of $\mathrm{Na}^{+}$in shoot decreased significantly with the increase of $\mathrm{N}$ addition $(P ; 0.05)$, and the content of $\mathrm{Mg}^{2+}$ in shoot hardly changed. The total contents of mineral elements in shoot in the treatments with $150 \mathrm{~kg} \mathrm{~N} \mathrm{ha}{ }^{-1}$ and $180 \mathrm{~kg} \mathrm{~N} \mathrm{ha}^{-1}$ increased $27.6 \%$ and $34.2 \%$ compared with that in the control treatment, respectively. While the content of $\mathrm{K}^{+}$in shoot in the treatments with $150 \mathrm{~kg} \mathrm{~N} \mathrm{ha}^{-1}$ and $180 \mathrm{~kg} \mathrm{~N} \mathrm{ha}^{-1}$ increased $71.9 \%$ and $99.3 \%$ compared with that in the control treatment, the content of $\mathrm{Ca}^{2+}$ in shoot in the treatments with $90 \mathrm{~kg} \mathrm{~N}$ ha ${ }^{-1}$ to $210 \mathrm{~kg}$ $\mathrm{N} \mathrm{ha}^{-1}$ increased $45.0 \%$ to $80.7 \%$ compared with that in the control treatment, and the difference were all significant $(P ; 0.05)$. Instead, the content of $\mathrm{Na}^{+}$in shoot in the treatment with $120 \mathrm{~kg} \mathrm{~N}^{-1}$ to $180 \mathrm{~kg} \mathrm{~N}$ ha $^{-1}$ decreased significantly $32.3 \%, 30.9 \%$ and $40.8 \%$ compared with that in the control treatment $(P \nmid 0.05)$, respectively.

With the increase of $\mathrm{N}$ addition level, the ratio of $\mathrm{K}^{+} / \mathrm{Na}^{+}$and the ratio of $\mathrm{Ca}^{2+} / \mathrm{Na}^{+}$in shoot of $L$. chinensis also increased constantly (Fig.3). When $\mathrm{N}$ addition level reached $90 \mathrm{~kg} \mathrm{~N}^{-1}$ to $210 \mathrm{~kg} \mathrm{~N}^{-1}$, the ratio of $\mathrm{K}^{+} / \mathrm{Na}^{+}$in shoot increased 1.26 to 3.37 times compared with that in the control treatment, and the ratio of $\mathrm{Ca}^{2+} / \mathrm{Na}^{+}$in shoot increased 1.56 to 2.98 times compared with that in the control treatment, and the differences all reached significant levels $(P ; 0.05)$. However, when $\mathrm{N}$ addition level was $210 \mathrm{~kg} \mathrm{~N}$ $\mathrm{ha}^{-1}$, the both ratios decreased, but still higher than those in the control treatment. Comprehensive mineral elements content, $\mathrm{K}^{+} / \mathrm{Na}^{+}$and $\mathrm{Ca}^{2+} / \mathrm{Na}^{+}$in shoot, when $\mathrm{N}$ addition rates were $120 \mathrm{~kg} \mathrm{ha}^{-1}$ to $180 \mathrm{~kg} \mathrm{ha}^{-1}$ the mineral quality of $L$. chinensisreached the best state, and there was a significant difference compared with those in the control treatment.

\subsection{Soil characteristics}

\subsection{1 pH, EC and ESP}

Soil $\mathrm{pH}, \mathrm{EC}$ and ESP of $\mathrm{N}$ addition treatments decreased significantly compared with those of non-N addition treatment when $\mathrm{N}$ addition rate was more than $90 \mathrm{~kg} \mathrm{ha}^{-1}(P ; 0.05)$, and three indexes showed a downward trend with the increase of $\mathrm{N}$ addition rates (Fig.4). Compared with the treatment without $\mathrm{N}$ addition, soil $\mathrm{pH}$ of the $\mathrm{N}$ addition treatments with $90-210 \mathrm{~kg} \mathrm{ha}^{-1}$ decreased by 0.71-1.19 units, soil EC decreased by 
34.4\%-67.2\%, and soil ESP decreased by 55.7\%-65.3\%, respectively. In MSSL of L. chinensis, N addition can reduce effectively salinity and alkalinity of 0-20 cm soil.

\subsubsection{SOM, TN, AN and C/N}

In MSSL of L. chinensis, $\mathrm{N}$ addition also increased the contents of SOM, TN and AN, and reduced the ratio of carbon to nitrogen $(\mathrm{C} / \mathrm{N})$. With $\mathrm{N}$ addition rate increasing, the content of SOM increased in a straight line, and it reached a significant level when $\mathrm{N}$ addition rate was $60 \mathrm{~kg} \mathrm{ha}^{-1}$ compared with that of the control treatment $(P ; 0.05)$. When $\mathrm{N}$ addition rates were $150-210 \mathrm{~kg} \mathrm{ha}^{-1}$, the contents of SOM increased 2.16-2.53 times compared with that of the control treatment (Fig.5A). Similarly, soil TN and AN contents were also improved significantly with $\mathrm{N}$ addition rates increasing $(P ; 0.05)$. Soil TN content was the highest when $\mathrm{N}$ addition rate reached $150 \mathrm{~kg} \mathrm{ha}^{-1}$, and increased by $269.3 \%$ compared with that of the treatment without $\mathrm{N}$ addition (Fig.5B). Soil AN content was the highest when $\mathrm{N}$ addition rate reached $180 \mathrm{~kg} \mathrm{ha}^{-1}$, and increased by $255.1 \%$ compared with that of the treatment without $\mathrm{N}$ addition (Fig.5C). Nitrogen addition significantly decreased the soil $\mathrm{C} / \mathrm{N}(P<0.05)$. The $\mathrm{C} / \mathrm{N}$ ratio of the $\mathrm{N}$ addition treatments with $90-210 \mathrm{~kg} \mathrm{ha}^{-1}$ was stable at about 15 (14.6-16.1), and those were lower by $38.3 \%-44.3 \%$ than that of the control treatment without $\mathrm{N}$ addition (Fig.5D).

\subsubsection{Soil enzyme activity}

Soil enzyme activity is a living index to reflect soil environmental changes and fertility conditions, and they are more sensitive to soil environment. In MSSL, with $\mathrm{N}$ addition rates increasing, soil urease and sucrase activities increased significantly $(P<0.05)$, and soil catalase activity decreased gradually (Table 1$)$. The soil urease activities in the $\mathrm{N}$ addition treatments with $90-210 \mathrm{~kg} \mathrm{ha}^{-1}$ increased by $91.5 \%-110.6 \%$ compared with that in no $\mathrm{N}$ addition treatment, and the soil sucrase activities increased by 3.74-5.42 times, respectively. On the contrary, the soil catalase activities in the $\mathrm{N}$ addition treatments with $90-210 \mathrm{~kg} \mathrm{ha}^{-1}$ decreased by $3.2 \%-13.6 \%$ compared with that in no $\mathrm{N}$ addition treatment.

\subsection{The relationship between L.chinensis quality and soil chemical characteristics}

In order to clarify the effects of soil salinity and nutrients on the quality of $L$. chinensis, RDA was conducted between $L$. chinensis quality and soil chemical characteristics. The results of RDA revealed that the variance ratio of RDA1 $(35.20 \%)$ reached a significant level in the biplot $(P<0.01)$, there were some negative correlations between soil salinity (pH, EC and ESP) and most quality indexes of L. chinensis (except for $\mathrm{Na}^{+}$and coarse fiber content), and there were some positive correlations between SOM, Sucrase, Urease and most quality indexes (Fig.6). RDA also indicated that L. chinensis had higher $\mathrm{Na}^{+}$and coarse fiber in no $\mathrm{N}$ addition or low $\mathrm{N}$ addition treatments ( $\mathrm{N} \mathrm{0-90),} \mathrm{which} \mathrm{was} \mathrm{mainly} \mathrm{related} \mathrm{to} \mathrm{higher} \mathrm{salinity} \mathrm{in} \mathrm{soil,} \mathrm{on}$ the contrary,L. chinensis had higher contents of $\mathrm{K}^{+}, \mathrm{Ca}^{2+}, \mathrm{Mg}^{2+}$, protein and fat in high $\mathrm{N}$ addition treatments (N 120-210), which was mainly related to higher SOM contents, urease and sucrose activities. Thus, $\mathrm{N}$ addition increased the quality of L. chinensis mainly through improved soil nutrient contents, especially carbon and $\mathrm{N}$ contents in saline-sodic soils.

\subsection{Ecosystem multifunctionality}

Nitrogen addition significantly affected the EMF of L. chinensis grassland in saline-sodic soil (Fig.7). The analysis of one way ANOVA showed that there were significant differences on the EMF of L. chinensisgrassland under different $\mathrm{N}$ addition rates $(\mathrm{F}=35.33, P<0.001$, Fig.7A). The EMF was negative when $\mathrm{N}$ addition rates were from 0 to $60 \mathrm{~kg} \mathrm{ha}^{-1}$, and the EMF was positive while $\mathrm{N}$ addition rates were from 90 to $210 \mathrm{~kg} \mathrm{ha}^{-1}$. This demonstrated that the EMF of L. chinensis grassland increased with $\mathrm{N}$ addition rates increasing in saline-sodic soil, but the EMF didn't increase when $\mathrm{N}$ addition rates reached enough levels (from 120 to $210 \mathrm{~kg} \mathrm{ha}^{-1}$ in the study). It was found that the relationship between the EMF and $\mathrm{N}$ addition level was quadratic curve model $\left(\mathrm{R}^{2}=0.88116, P<0.0001\right.$, Fig.7B). In the study, the EMF was the maximum when $\mathrm{N}$ addition rates were 150 or $180 \mathrm{~kg} \mathrm{ha}^{-1}$, while the EMF would decrease if $\mathrm{N}$ addition rate reached at $210 \mathrm{~kg} \mathrm{ha}^{-1}$. Therefore, the EMF of $L$. chinensisgrassland was affected by $\mathrm{N}$ addition rates to a large extent in saline-sodic soil of Northeast China. 


\section{Discussion}

\subsection{Effect of $N$ addition on the quality of L. chinensis}

Our previous studies have demonstrated that $\mathrm{N}$ addition can increase hay yield of L. chinensis and inhibit grassland degradation in different saline-sodic soils, and determined the optimum $\mathrm{N}$ addition rate was 90 to $120 \mathrm{~kg} \mathrm{~N} \mathrm{ha}^{-1}$ in MSSL according to the yield and $\mathrm{N}$ use efficiency (Huang et al ., 2015). Many other researchers have also reported that $\mathrm{N}$ addition improved the quality of various herbages (Chen \& Carran,1990;Dong et al .,2008; Tan et al. ,2014;Hu et al. , 2017). However, the effect of $\mathrm{N}$ addition on the quality of $L$. chinensis was rarely studied in saline-sodic grassland. It is very worth studying how long-term continuous $\mathrm{N}$ application will affect the quality of L. chinensis in MSSL.

The results of this experiment indicated that the protein and fat contents of $L$. chinensis were significantly increased by $\mathrm{N}$ addition for 10 years in MSSL, and the coarse fiber and ash contents did not change significantly under different $\mathrm{N}$ addition levels (Fig.1). In saline or alkali condition, Leymus chinensis usually has high protein content (Shi et al. , 2008; Zhou et al. , 2009). Generally, N addition increased the protein and fat contents and decreased the coarse fiber content of L. chinensis, which has been confirmed by many studies (Dong et al. , 2014; Bai et al. , 2017; Hu et al. , 2017). Previous studies also demonstrated that N addition did not affect the ash content of more plants (Brownet al. , 1932; Dong et al. , 2014).

Furthermore, $\mathrm{N}$ addition had a positive effect on the optimization of ion-allocated proportion in L. chinensis plants, and the content of $\mathrm{K}^{+}$and $\mathrm{Ca}^{2+}$ in L. chinensis plants increased, while the content of $\mathrm{Na}^{+}$decreased with $\mathrm{N}$ addition rates increasing (Fig.2). The ratio of $\mathrm{K}^{+} / \mathrm{Na}^{+}$and $\mathrm{Ca}^{2+} / \mathrm{Na}^{+}$in L. chinensisshoot also increased with $\mathrm{N}$ addition rates increasing (Fig.3). The ratio of $\mathrm{K}^{+} / \mathrm{Na}^{+}$and $\mathrm{Ca}^{2+} / \mathrm{Na}^{+}$in shoot of plants was usually regarded as an important index of salt tolerance (Huang et al ., 2008). Under N addition, both of them increasing indicated that the toxicity of sodium ions to L. chinensis was reduced (Yinet al. , 1993) and salt tolerance of $L$. chinensis was enhanced ( $\mathrm{Li}$ et al. ,2002). Therefore, the reasonable $\mathrm{N}$ addition not only improved the quality of $L$. chinensis, but also improved its salt tolerance and reduced the degradation of saline-sodic grassland.

\subsection{Effect of $\mathrm{N}$ addition on soil characteristics}

With the development of modern agriculture, nutrient addition (especially $\mathrm{N}$ addition) has become an essential cultivation measure to improve the productivity of most food crops and forages. However, the influences of long-term fertilization on cultivated soil have also aroused widespread concern in recent decades. For example, long-term application of $\mathrm{N}$ fertilizer resulted in the decline of SOM in black soil in Northeast China (Qiao et al. , 2007), and the aggravation of soil acidification in Southern China, soil pH dropped by 0.5 units in past 20 years (Guo et al. , 2010). So far, little research had been done about the effect of $\mathrm{N}$ addition on the characteristics of saline-sodic soil. Our results in saline-sodic paddy field showed that the $\mathrm{N}$ addition level had no significant effects on soil $\mathrm{pH}$ and $\mathrm{EC}$ in the short term (3 years), but the soil $\mathrm{N}$ contents were significantly increased, soil $\mathrm{pH}$ and EC also decreased significantly with cultivation time increasing (Huang et al. , 2016). In this study, soil $\mathrm{pH}, \mathrm{EC}$ and ESP decreased significantly when $\mathrm{N}$ addition rate was more than ha $^{-1}$ after 10 years of continuous N addition (Fig.4). Similar results were also found in alfalfa pastures in North America and mountain heathlands in Spain (Chen et al. , 2001; Marcos et al ., 2003). These results further indicated that long-term continuous $\mathrm{N}$ addition had a positive effect on reducing grassland salinization.

Many literatures have demonstrated that $\mathrm{N}$ addition improved soil fertility, especially in some marginal lands (Wang \& An, 2010; Liet al. , 2017; Kumar et al. , 2019). Our previous study also showed that soil inorganic $\mathrm{N}$ and TN contents increased significantly in the $0-20 \mathrm{~cm}$ soil layer of saline-sodic paddy field with the increasing of cultivation years or $\mathrm{N}$ application rates (Huang et al. , 2016). The experimental results indicated that the contents of SOM, TA and AN under different $\mathrm{N}$ addition rates were significantly increased $(P<0.05)$ than those of no $\mathrm{N}$ treatment after 10 years of continuous $\mathrm{N}$ addition in $L$. chinensis grassland (Fig.5). However,compared with the experimental results of 7 years ago (Huanget al. , 2015), the contents 
of TA and AN in soils from different $\mathrm{N}$ treatments had little change. Under the condition of continuous $\mathrm{N}$ addition for many years in saline-sodic grassland, in addition to increasing the hay yield of L. chinensis , where did the rest of the $\mathrm{N}$ go? Why can't soil $\mathrm{N}$ content be further improved? These problems should be further studied in the future.

Interestingly, with $\mathrm{N}$ addition rates increasing, the content of $\mathrm{SOM}$ increased significantly, while $\mathrm{C} / \mathrm{N}$ ratio decreased significantly in saline-sodic grassland of L. chinensis $(P<0.05$, Fig.5A \& 5D). The soil C/N ratio was maintained at about 15:1 when $\mathrm{N}$ addition rate was more than $90 \mathrm{~kg} \mathrm{~N}$ ha-1, which was close to the conventional value of SOM. Some studies had pointed out that soil $\mathrm{C} / \mathrm{N}$ ratio usually directly influences the nitrification and denitrification process of soil microorganisms, and then affects the conversion and discharge of soil N (Rizhiya, et al. , 2011; Kraft, et al. , 2014). In this experiment, soil C/N ratios were higher in the original saline-sodic grassland without $\mathrm{N}$ addition and the treatment with $\mathrm{N}$ addition rate less than $60 \mathrm{~kg} \mathrm{~N}$ $\mathrm{ha}^{-1}$, so the growth of $L$. chinensis shoot was inhibited. Therefore, $\mathrm{N}$ addition can increase the aboveground yield of plants and improve the quality of plants/soils (Mou, 2015; Chang et al. , 2017).

Based on the analysis of soil enzyme activities related to the transformation of soil $\mathrm{C}, \mathrm{N}$ and $\mathrm{P}$, it was found that the activities of soil sucrase and urease increased significantly with $\mathrm{N}$ addition rates increasing $(P<0.05)$, while the activities of catalase decreased, and there was no significant difference among different $\mathrm{N}$ treatments (Table.1). Many previous studies have also demonstrated that urease activity increased significantly and promoted $\mathrm{N}$ fertilizer hydrolysis and mineralization under exogenous $\mathrm{nN}$ addition (Ge et al ., 2010), thus, more absorbable $\mathrm{N}$ was provided for plants (Aerts \& Chapin, 1999). The similar changes of soil sucrase activity indicated that exogenous $\mathrm{N}$ promoted plant growth and increased soil organic carbon pool (Zhao et al. , 2008), while the response of soil catalase activity to exogenous $\mathrm{N}$ addition was almost insignificant (Song et al. , 2009; Wang et al. , 2015; Peng et al. , 2017).

\subsection{The optimum of $\mathrm{N}$ addition and its effects on multifunctionality}

Our previous study determined the optimal $\mathrm{N}$ addition rate was 90 to $120 \mathrm{~kg} \mathrm{~N} \mathrm{ha}^{-1}$ in MSSL according to the hay yield and $\mathrm{N}$ use efficiency (Huang et al. , 2015). The overall results of this study strongly support this conclusion again from the quality of $L$. chinensis and soil characteristics. Although $L$. chinensis may have the maximum seed yield when $\mathrm{N}$ addition rate was $150 \mathrm{~kg} \mathrm{~N}$ ha-1 in MSSL(Huang et al. , 2019) and other higher quality indicators, such as protein contents and $\mathrm{K}^{+} / \mathrm{Na}^{+}$ratio in this study, comprehensive analysis indicated that this recommendation was still the best. The relationship between L.chinensis quality and soil chemical characteristics also fully illustrated that soil desalination was consistent with the improvement of soil fertility and plant quality (Fig.6), and $\mathrm{N}$ addition was beneficial to achieve the goal.

In recent years, there has seen a surge of interest in ecosystem multifunctionality which including 'ecosystem function multifunctionality' and 'ecosystem service multifunctionality' (Manninget al. , 2018). As a whole, the EMF has been widely studied in natural ecosystem (Pfisterer \& Schmid, 2002). In this study, the effect of $\mathrm{N}$ addition on the EMF of $L$. chinensis showed a quadratic curve relationship, and there was a positive correlation between the EMF and $\mathrm{N}$ addition rates of more than $90 \mathrm{~kg} \mathrm{~N}$ ha-1(Fig.7). When $\mathrm{N}$ addition rate was 120 to $210 \mathrm{~kg} \mathrm{~N}^{-1}$, there were no significant changes on the EMF among different $\mathrm{N}$ treatments, indicating that the EMF basically reached a steady state. Consequently, $\mathrm{N}$ addition of $90-120 \mathrm{~kg} \mathrm{~N}^{-1}$ was also suitable in moderately saline-sodic grassland of $L$. chinensis from the perspective of the EMF.

\section{Conclusions}

It took nearly 10 years to conduct a field experiment of $\mathrm{N}$ addition on L. chinensis in MSSL. Nitrogen addition not only increased the contents of protein and fat, the ratio of $\mathrm{K}^{+} / \mathrm{Na}^{+}$and $\mathrm{Ca}^{2+} / \mathrm{Na}^{+}$of L. chinensisshoot, but also decreased the degree of soil salinization and increased soil fertility and the EMF. The suitable $\mathrm{N}$ addition rate of 90-120 $\mathrm{kg} \mathrm{N}^{-1}$ effectively inhibited the yield, quality and soil degradation of L. chinensis in MSSL. Thus, scientific data once again proved that $\mathrm{N}$ addition was an effective and necessary measure 
to maintain the healthy growth of $L$. chinensis and inhibit land degradation in saline-sodic grassland of northern China.

\section{Conflicts of interest}

Authors do not have any conflicts of interest.

\section{Acknowledgements}

This research was supported by the National Natural Science Foundation of China (41977148),and National Key R\&D Program (2016YFD0200303) and National Key Basic Research Program of China (2015CB150803).

\section{Data Availability Statement}

The data that support the findings of this study are available from the corresponding author upon reasonable request.

\section{References}

Aerts, R., \& Chapin III, F. S. (1999). The mineral nutrition of wild plants revisited: a re-evaluation of processes and patterns. InAdvances in ecological research (Vol. 30, pp. 1-67): Elsevier.

Bai, Y. F., Han, X. G., Wu, J. G., Chen, Z. Z., \& Li, L. H. (2004). Ecosystem stability and compensatory effects in the Inner Mongolia grassland. Nature, 431 (7005), 181-184. http://doi:10.1038/nature02850 (In Chinese.)

Bao, S.D. (2000) 'Soil and agricultural chemical analysis.' 3rd edn. pp. 42-58.(Agriculture Press: Beijing) (In Chinese.)

Brown, B. (1932). The Effects of Fertilization on the Chemical Composition of Vegetation in Pastures 1. Agronomy Journal, 24 (2), 129-145. http://doi:10.2134/agronj1932.00021962002400020

Chang, J. F., Dong, P. F., Wang, X. L., Liu, W. L., \& Li, H., Chao. (2017). Effects of nitrogen application on carbon and nitrogen metabolism of different summer maize varieties. Scientia Agricultura Sinica, 50 (12), 2282-2293. (In Chinese.)

Chen, W., McCaughey, W. P., Grant, C. A., \& Bailey, L. D. (2001). Pasture type and fertilization effects on soil chemical properties and nutrient redistribution. Canadian Journal of Soil Science, 81 (4), 395-404. http://doi:10.4141/s99-103

Chen, Z. Z., \& Carran, A. (1990). The effects of appling nitrogen fertilizers in Autumn on the biomass and quality of grasses. Grassland of China (China), 2 , 19-23. (In Chinese.)

Clark, C. M., \& Tilman, D. (2008). Loss of plant species after chronic low-level nitrogen deposition to prairie grasslands. Nature, 451 (7179), 712-715. http://doi:10.1038/nature06503

Dong, X. B., Hao, M. D., Guo, S., Shi, X., Ma, T., Liu, P., \& Liu, G. (2014). Fertilization effects on hay yield and quality of Leymus chinensis . Pratacult Sci, 31 (10), 1935-1942. (In Chinese.)

Dong, Z. R., Tian, L. Z., Zhao, B., Wu, D. C., \& Zhu, Y. G. (2008). Effects of nitrogen application on the yield and quality of Triticale cereale. Pratacultural Science, 25 (5), 64-67. (In Chinese.)

Gao, C., Zhang, Y. X., Chen, J. S., Di, G. L., Pan, D. F., Wang, J. L., . . . Zhong, P. (2015). Analysis of soil nitrogen dynamics of Medicago sativa and Leymus chinensis pasture in the Songnen Plain.Pratacultural Science, 32 (4). http://doi:10.11829\j.issn.1001-0629.2014-0315 (In Chinese.)

Ge, G., Li, Z., Fan, F., Chu, G., Hou, Z., \& Liang, Y. (2010). Soil biological activity and their seasonal variations in response to long-term application of organic and inorganic fertilizers. Plant and Soil, 326 (1-2), 31. 
Guan, S.Y., et al. Soil enzymes and the research methods. Agriculture Press: Beijing.1986. (In Chinese.)

Guo, J. H., Liu, X. J., Zhang, Y., Shen, J. L., Han, W. X., Zhang, W. F., . . . Zhang, F. (2010). Significant acidification in major Chinese croplands. Science, 327(5968), 1008-1010. http://doi:10.1126/science.1182570

Hajiboland, R. (2013). Role of Arbuscular Mycorrhiza in Amelioration of Salinity. In Salt Stress in Plants (pp. 301-354).

Hector, A., \& Bagchi, R. (2007). Biodiversity and ecosystem multifunctionality. Nature, 448 (7150), 188-190. http://doi:10.1038/nature05947

Hu, D.X., Wang, J.L., Pan, D.F., Zhang, R.B., Li, D.M., Tang, F.L., Shen, Z.B.. Effects of fertilization on yield and quality ofLeymus chinensis cultivated grassland. Chinese Journal of Grassland, 2017, 39(01):35-41. (In Chinese.)

Huang, L. H., \& Liang, Z. W. (2008). Ionic absorption characteristics of Leymus chinensis seeded in various pH soils. Chinese Journal of Grassland, 1, 35-39. (In Chinese.)

Huang, L. H., Liang, Z. W., Suarez, D. L., Wang, Z. C., \& Wang, M. M. (2019). Effects of continuous nitrogen application on seed yield, yield components and nitrogen-use efficiency of Leymus chinensis in two different saline-sodic soils of Northeast China. Crop and Pasture Science, 70 (4). http://doi:10.1071/cp18274

Huang, L. H., Liang, Z. W., Suarez, D. L., Wang, Z. C., Wang, M. M., Yang, H. Y., \& Liu, M. (2016). Impact of cultivation year, nitrogen fertilization rate and irrigation water quality on soil salinity and soil nitrogen in saline-sodic paddy fields in Northeast China. The Journal of Agricultural Science, 154 (4), 632. http://doi:10.1017/s002185961500057x

Huang, L., Liang, Z., Suarez, D. L., Wang, Z., Ma, H., Wang, M., . . . Liu, M. (2015). Continuous Nitrogen Application Differentially Affects Growth, Yield, and Nitrogen Use Efficiency of Leymus chinensis in Two Saline-Sodic Soils of Northeastern China. Agronomy Journal, 107 (1), 314-322. http://doi:10.2134/agronj14.0250

Jin, H., Kim, H. R., Plaha, P., Liu, S. K., Park, J. Y., Piao, Y. Z., . . . Lim, Y. P. (2008). Expression profiling of the genes induced by $\mathrm{Na} 2 \mathrm{CO} 3$ and $\mathrm{NaCl}$ stresses in leaves and roots of Leymus chinensis .Plant Science, 175 (6), 784-792. http://doi:10.1016/j.plantsci.2008.07.016

Jing, X., Sanders, N. J., Shi, Y., Chu, H., Classen, A. T., Zhao, K., . . . He, J. S. (2015). The links between ecosystem multifunctionality and above- and belowground biodiversity are mediated by climate. Nat Commun, 6 , 8159. http://doi:10.1038/ncomms9159

Kraft, B., Tegetmeyer, H. E., Sharma, R., Klotz, M. G., Ferdelman, T. G., Hettich, R. L., . . . Strous, M. (2014). Nitrogen cycling. The environmental controls that govern the end product of bacterial nitrate respiration. Science, 345 (6197), 676-679. http://doi:10.1126/science.1254070

Kumar, P., Lai, L., Battaglia, M. L., Kumar, S., Owens, V., Fike, J., . . . Viands, D. (2019). Impacts of nitrogen fertilization rate and landscape position on select soil properties in switchgrass field at four sites in the USA. Catena, 180 , 183-193. http://doi:10.1016/j.catena.2019.04.028

Li, P. P., Wang, B., Liu, G. B., \& Li, B. B. (2017). Effects of nitrogen addition on the population characteristics of Bothriochloa ischaemum and soil properties. Science of Soil and Water Conservation, 015 (002), 35-42. (In Chinese.)

Li, S. H., Xu, X., Hui, H. X., Mi, H. L., \& Ma, X. Q. (2002). Study on $\mathrm{K}^{\wedge}+, \mathrm{Na}^{\wedge}+$ selective absorption of different organs of spring wheat under soil saline sodic stress in different growth season. Acta Botanica Boreali Occidentalia Sinica, 22 (3), 587-594. http://doi:10.3321/j.issn:1000-4025.2002.03.020 (In Chinese.)

Manning, P., Van der Plas, F., Soliveres, S., Allan, E., Maestre, F. T., Mace, G., . . . Fischer, M. (2018). Redefining ecosystem multifunctionality. Nat Ecol Evol, 2 (3), 427-436. http://doi:10.1038/s41559-0170461-7 
Marcos, E., Calvo, L., \& Luis-Calabuig, E. (2003). Effects of fertilization and cutting on the chemical composition of vegetation and soils of mountain heathlands in Spain. Journal of Vegetation Science, 14 (3), 417-424. http://doi:10.1111/j.1654-1103.2003.tb02167.x

Mou, X. Effect of nitrogen addition on stoichiometry of carbon, nitrogen and phosphotus in grassland. China Water, 2015,15(3):100-101. (In Chinese.)

Murtaza, G., Hussain, N., \& Ghafoor, A. (2000). Growth response of rice (Oryza sativa L.) to fertilizer nitrogen in salt-affected soils.Int. J. Agric. Biol, 2 , 204-206.

Peng, C. J., Li, Q., Gu, H. H., \& Song, X. Z. (2017). Effects of simulated nitrogen deposition and management type on soil enzyme activities in Moso bamboo forest. Chinese Journal of Applied Ecology, 28 (2), 423-429. http://doi:10.13287/j.1001-9332.201702.001(In Chinese.)

Pfisterer, A. B., \& Schmid, B. (2002). Diversity-dependent production can decrease the stability of ecosystem functioning. Nature, 416 (6876), 84-86. http://doi:10.1038/416084a

QI, H., LUO, W., SUN, Y. J., \& GUO, J. X. (2013). Responses ofLeymus chinensis quantity characteristic to simulated warming and nitrogen application in Songnen Grassland. Journal of Northeast Normal University (Natural Science Edition) (2), 20. (In Chinese.)

Qiao, Y. F., Han, X. Z., Han, B. J., Li, H.-b., \& Wang, S. Q. (2007). Soil organic carbon and nitrogen of black farmland growth and decline under a long-term experiment chemical fertilizer applications [J].Soil and Fertilizer Sciences in China, 4. (In Chinese.)

Qin, Y., He, F., Tong, Z. Y., Xie, K. Y, Wang, D., Gammal, Quan, G.L., Song, Q., Wang Hu, ... Xiang, L. Influence of fertilizer use on nitrogen transformation in soils of the Leymus chinensis steppe. Acta Prataculturae sinica, 2016, 25(10):48-55. http://doi:10.11686/cyxb2015561 (In Chinese.)

Rizhiya, E. Y., Boitsova, L., Buchkina, N., \& Panova, G. (2011). The influence of crop residues with different C: $\mathrm{N}$ ratios on the $\mathrm{N}_{2} \mathrm{O}$ emission from a loamy sand soddy-podzolic soil.Eurasian Soil Science, 44 (10), 1144. http://doi:10.1134/S1064229311100115

Setia, R., Gottschalk, P., Smith, P., Marschner, P., Baldock, J., Setia, D., \& Smith, J. (2013). Soil salinity decreases global soil organic carbon stocks. Science of The Total Environment, 465 , 267-272. http://doi:10.1016/j.scitotenv.2012.08.028

Shi, L. X., Gong, L., Hu, Y. J., \& Guo, J. X. (2008). Study on the soluble carbohydrate and soluble protein of Leymus chinensiswintering rhizome in different saline-alkaline glassland. Journal of Northeast Normal University (Natural Science Edi tion) 2008(02):88-92. (In Chinese.)

Singh, K. (2015). Microbial and Enzyme Activities of Saline and Sodic Soils. Land Degradation \& Development, 27 (3), 706-718. http://doi:10.1002/ldr.2385

Song, X. G., Hu, T. X., Xian, J. R., \& Xiao, C. L. (2009). Soil enzyme activities and its response to simulated nitrogen deposition in an evergreen broad-leaved forest, southern Sichuan. Acta Ecologica Sinica, 29 (3), 1234-1240. http://doi:10.1007/978-1-4020-9623-5_5 (In Chinese.)

Song, Y. T., Li, Q., Wang, P., Zhou, D. W., \& Wu, Y. N. (2016). Response of Leymus chinensis functional traits and aboveground biomass to nitrogen addition in Songnen grassland in northeast China.Pratacult Sci, 33 (7), 1383-1390. (In Chinese.)

Tan, S.Y., Wei, L.M., Wang, F., et al. Effect of urea on fermentation quality of Sudan grass silage. China Feed , 2014, (17 ):18-19+22. (In Chinese.)

Vitousek, P. M., Naylor, R., Crews, T., David, M. B., Drinkwater, L. E., Holland, E., . . . Zhang, F. S. (2009). Nutrient imbalances in agricultural development. Science, 324 (5934), 1519-1520. http://doi:10.1126/science.1170261 
Wang, G.F. \& An, S.Z. Effect of Fertilizers on Soil Fertility,Population Structure and Yield of Herbages in Degraded Grassland. Modern Agricultural Science and Technology, 2010(09):278+287. (In Chinese.)

Wang, P., Yin, L. J., \& Li, J. D. (1994). Studies on the adaptabity and to lerance of Leymus chinensis to salinity in salinized grassland in the Songnen plain. Acta Ecologica Sinica, 14 (3), 306-311. (In Chinese.)

WANG, Y. Y., CHEN, S. T., LIU, Y. F., \& ZHAI, X. Y. (2015). Effects of exogenous nitrogen addition on carbon dioxide emission and enzyme activities of a forest soil. Chinese Journal of Ecology (5), 3. http://doi:10.13292/j.1000-4890.20150311.039 (In Chinese.)

Wang, Z. M., Song, K. S., Zhang, B., Liu, D. W., Ren, C. Y., Luo, L., . . . Liu, Z. M. (2009). Shrinkage and fragmentation of grasslands in the West Songnen Plain, China. Agriculture, Ecosystems \& Environment, 129 (1-3), 315-324. http://doi:10.1016/j.agee.2008.10.009

Wong, V. N. L., Greene, R. S. B., Dalal, R. C., \& Murphy, B. W. (2010). Soil carbon dynamics in saline and sodic soils: a review. Soil use and management, 26 (1), 2-11. http://doi:10.1111/j.1475-2743.2009.00251.x

Xu M.G., Li D.C., Li J.M., Qin D.Z., Kazuyuki Yagi, Yasukazu Hosen. Effects of Organic Manure Application Combined with Chemical Fertilizers on Nutrients Absorption and Yield of Rice in Hunan of China. Scientia Agricultura Sinica, 2008(10):3133-3139. (In Chinese.)

Yin, L. J., Shi, D. C., \& Wang, P. (1993). Growth adaptability and salt tolerance osmoregulation of Aneurolepidium chinense grown on saline grassland. Journal of Integrative Plant Biology, 35 (8). (In Chinese.)

Zhang, F. S., Wang, J. Q., Zhang, W. F., Cui, Z. L., Ma, W. Q., Chen, X. P., \& Jiang, R. F. (2008). Nutrient use efficiencies of major cereal crops in China and measures for improvement. Acta Pedologica Sinica, 45 (5), 915-924. http://doi:10.3321/j.issn:0564-3929.2008.05.018 (In Chinese.)

Zhang, L., Huang, J. H., Bai, Y. F., \& Han, X. G. (2009). Effects of nitrogen addition on net nitrogen mineralization in Leymus chinensis grassland, Inner Mongolia, China. Journal of Plant Ecology (Chinese Version), 33 (3), 563-569. (In Chinese.)

Zhao, Y. t., Li, X. F., Han, S. J., \& Hu, Y. L. (2008). Soil enzyme activities under two forest types as affected by different levels of nitrogen deposition. Chinese Journal of Applied Ecology, 19 (12), 2769-2773. (In Chinese.)

Zhou, C., Zou, Z. Y., \& YANG, Y. F. (2009). Effect of salt-alkali stress on soluble protein of Leymus chinensis . Journal of Northeast Normal University (Natural Science Edition), 3 (41), 94-96. (In Chinese.)

Zhu, Y. C. (2004). Yang-Cao biological ecology. Changchun: Jilin Science and Technology Press (In Chinese).

\section{Hosted file}

Table 1.docx available at https://authorea.com/users/355836/articles/478944-effects-ofcontinuous-nitrogen-addition-on-the-quality-of-leymus-chinensis-and-soil-properties-insaline-sodic-soil-of-northeast-china

\section{Hosted file}

Fig.1.docx available at https://authorea.com/users/355836/articles/478944-effects-ofcontinuous-nitrogen-addition-on-the-quality-of-leymus-chinensis-and-soil-propertiesin-saline-sodic-soil-of-northeast-china

\section{Hosted file}

Fig.2.docx available at https://authorea.com/users/355836/articles/478944-effects-ofcontinuous-nitrogen-addition-on-the-quality-of-leymus-chinensis-and-soil-propertiesin-saline-sodic-soil-of-northeast-china 


\section{Hosted file}

Fig.3.docx available at https://authorea.com/users/355836/articles/478944-effects-ofcontinuous-nitrogen-addition-on-the-quality-of-leymus-chinensis-and-soil-propertiesin-saline-sodic-soil-of-northeast-china

\section{Hosted file}

Fig.4.docx available at https://authorea.com/users/355836/articles/478944-effects-ofcontinuous-nitrogen-addition-on-the-quality-of-leymus-chinensis-and-soil-propertiesin-saline-sodic-soil-of-northeast-china

\section{Hosted file}

Fig.5.docx available at https://authorea.com/users/355836/articles/478944-effects-ofcontinuous-nitrogen-addition-on-the-quality-of-leymus-chinensis-and-soil-propertiesin-saline-sodic-soil-of-northeast-china

\section{Hosted file}

Fig.6.docx available at https://authorea.com/users/355836/articles/478944-effects-ofcontinuous-nitrogen-addition-on-the-quality-of-leymus-chinensis-and-soil-propertiesin-saline-sodic-soil-of-northeast-china

\section{Hosted file}

Fig.7.docx available at https://authorea.com/users/355836/articles/478944-effects-ofcontinuous-nitrogen-addition-on-the-quality-of-leymus-chinensis-and-soil-propertiesin-saline-sodic-soil-of-northeast-china 